\title{
PHILOSTRATUS' HEROIKOS: PROTESILAOS, ACHILLES AND PALAMEDES UNITE IN DEFENCE OF THE GREEK WORLD.*
}

\author{
Mark Kirby-Hirst \\ University of Pretoria
}

\begin{abstract}
Philostratus' Heroikos is a dialogue between a vinedresser, tending the sanctuary of the hero, Protesilaos, and a Phoenician merchant. By reading this dialogue in tandem with the Vita Apollonii, which includes several notable instances engaging with the hero-cult, Philostratus' opinion of this traditional form of Greek worship, and of the Eastern mystery cults as well, becomes clear. Philostratus initially expresses his displeasure at the religious status quo of his time through his character of Apollonius of Tyana, a time when mystery cultism was beginning to overthrow the ancient rites of the Olympian deities with its individualistic approach to belief. This article argues that together, these two works provide evidence of a call by Philostratus to renew the worship of the old Homeric heroes as a viable replacement for the declining rites of the Olympian gods, and as an attack on mystery rites as foreign intrusions on the religious landscape.
\end{abstract}

\section{Introduction}

Flavius Philostratus was working at an intriguing time in the social and religious history of the Mediterranean world, a time which he calls the 'Second Sophistic' (Philostr. VS 481). The early 3rd century CE was also a time during which Philostratus witnessed the steady expansion of new religious alternatives in the Roman Empire, ${ }^{1}$ alternatives that saw the old paradigm of Olympian 'polis-

\footnotetext{
* My sincere thanks to the University of Pretoria and its Department of Ancient Languages for their financial support during the finalising of this article. I must also express my incredible appreciation to Dr Beschara Karam, my critical reader, without whose help, support, and thoughtful criticism, this article would never have been completed. Finally, I must acknowledge the assistance of the Acta Classica referees, whose comments have greatly enhanced this work of scholarship.

${ }^{1}$ Rather than making use of the typical 'oriental' designation (with all of its baggage) for these Eastern rites that had entered the imperial religious scene, this article primarily refers to either 'alternative religions' or 'Eastern alternative religions'. It should also be noted that the use of the word 'Eastern' in describing these alternative belief systems refers only to the fact that they derived from the eastern parts of the Roman Empire.
}

DOI 10.15731/AClass.057.05 
religion ${ }^{2}$ increasingly marginalised in favour of the individually focused rites that were typical of the teachings of Eastern alternative religions like early Christianity, belief systems that were far less attuned to extant 'polis boundaries and the social order. ${ }^{3}$ Nowhere could his disproval for these newer Eastern cultic systems be argued to be more apparent than in his construct of Apollonius of Tyana, through whom, it is contended, Philostratus emphasises a return to tradition and the paring down of foreign additions to pre-existing rites in order to revert to a shared core of belief (Philostr. VA 1.2; 1.16.3; 4.1-24). Apollonius is even made to discover that the greatest mystics in the East, the Brahmins of India, ascribe to the earliest traditions of Greek religious praxis rather than any Eastern belief (Philostr. VA 3.14.3). However, this article only makes mention of Apollonius and his activities in conjunction with a core discussion of Philostratus' Heroikos, ${ }^{4}$ a dialogue that can potentially be read as arguing for the place of Greek traditional belief in a world of new and foreign ideologies.

This particular choice of descriptive terminology is because both the terms 'oriental' and 'cult' betray both prejudice and false assumptions. It is nonetheless important to note that Cumont 1956, despite his introduction of the 'oriental cult' descriptor, also points out a general similarity in these beliefs, namely their attraction to potential worshippers because of the promise of a good afterlife. The majority of these alternative religions provided what Kerenyi 1967:90 described as 'an experience of the "other" in a change of consciousness, moving far beyond what could be found in everyday life.' These religions, sometimes known collectively as 'mysteries', came in many varieties, some of which had been part of Greek society for centuries like the popular cult of Demeter and Korē at Eleusis, outside Athens. Others such as the worship of the Syrian mother goddess, Cybele, the Persian warrior god, Mithras, and even nascent Christianity had arrived more recently on the religious scene. All 'mystery' rites shared a common desire for secrecy which protected a central 'revelation' or 'truth' as to the nature of the relationship between the worshipper and the divine. Initiates into the 'mysteries' were all sworn to absolute secrecy about the rites in which they participated, and as such, little accurate first-hand information remains.

${ }^{2}$ The term was first used by Sourvinou-Inwood 1990, and specifies a unique paradigm of religious organisation whereby public cult was said to be concentrated on the needs of the city state as a whole, placing great importance on élite social and political matters.

${ }^{3}$ Woolf 1997:73. This is a key feature of the popularity of the Eastern alternative religions, simply because it allowed the lower classes to participate in worship in a manner typically reserved for the élite.

${ }^{4}$ Of the three Philostrati listed in the Suda, 'Philostratus II', whom Solmsen 1940:556 dubs 'Philostratus the Elder', is assigned the authorship of the Vitae Sophistarum, and Vita Apollonii. Solmsen 1940:556-72 goes on to argue that this same Philostratus the Elder is also responsible for writing the Heroikos. De Lannoy 1997:2391 concurs with Solmsen, but Anderson 1986:294-95 rejects the idea of the Heroikos being written by the same person as the Vita Apollonii. This article adopts the former position, namely 
In constructing the Heroikos, Philostratus initially appears to abandon the pan-Hellenic objectives personified in Apollonius of Tyana, turning instead to examine the subject of the Homeric heroes ${ }^{5}$ and their cult worship, something that held mass appeal among the Roman Empire's citizens, with the hero Protesilaos representing an especially popular example. While the correction of Homer may have been 'literary sport' during the Second Sophistic, ${ }^{6}$ in writing the Heroikos, Philostratus is not solely engaged in an intellectual exercise. Instead, it is argued that he seeks to distinguish his own unique religious perspective from the pan-Hellenic outlook that characterised earlier Homeric epic, in an effort to shed light on the ancient heroic belief system and why it came to hold far greater significance for the peoples of the Roman Empire than the Olympian deities. This article therefore sets out to investigate how Philostratus positions the Heroikos on the religious landscape of the Roman Empire during the Second Sophistic, and attempts to discern whether this dialogue represents an active Greek counterpoint to the growth and popularity of alternative Eastern religions.

It will be argued that Philostratus utilises two primary methods in his exploration of ancient hero-cult, namely the selection of the Homeric hero, Protesilaos, as his authoritative messenger for expounding on the religious tradition of the hero-cult, and the juxtaposition of his 'solution' of the Greek hero-cult with the increasingly popular alternative religions originating in the Near East. Philostratus spends a great deal of time detailing this relatively minor hero (in terms of the greater Homeric tradition) specifically because this allows him to mould Protesilaos for his own particular purposes. And what is more, Philostratus' revisionist presentation of the practice of hero-cult occurs within the stylistic and literary concerns of the Second Sophistic, ${ }^{7}$ while being circumscribed within the boundaries of Roman power and Greek pedagogy. Philostratus employs his version of Protesilaos in tandem with two other, more well-known heroes, namely Achilles and Palamedes. This three-pronged approach permits him to work towards the formulation of a true Hellenic

that the Heroikos was indeed penned by the same man responsible for giving us the literary character of Apollonius of Tyana, perhaps indeed as Solmsen 1940:569 suggests, that the Heroikos 'grew out of the subjects discussed in the Vita Apollonii.'

${ }^{5}$ These heroes originally derived from the time preceding Homer, as evidence in Linear B tablets indicates (Jones 2010:3), with the practice of creating heroes (heroisation) continuing for several centuries thereafter.

${ }^{6}$ Maclean \& Aitken 2002:1; cf. Solmsen 1941:col. 156

${ }^{7}$ Two key elements mark the Philostratean sophistic perspective, namely a 'determined Hellenism' that aimed at the revitalisation of the present through extolling the many achievements of the Greek past; and 'versatility', in terms of Philostratus' choice and manner of deploying canonical Greek tales for new purposes (Anderson 1993:17). 
paragon who can potentially function as a dramatic exemplar of the older heroic religious tradition, standing in opposition to newer beliefs. Given the multifaceted nature of these problems, it is necessary to approach this analysis over the course of several sections, beginning with a brief biography of the author, Flavius Philostratus, coupled with an outline of the period in which he was writing. This is followed by a discussion of the general principles of the ancient hero-cult as understood in the Hellenic world, along with discussion of the polis-religion paradigm as it functioned at the time of Philostratus, before finally addressing the Philostratean repositioning of the hero-cult as a reaction to the popularity of alternative Eastern religions as argued through the Heroikos. This argument is supplemented by a discussion of the hero-cult as it is described in another of Philostratus' works, the Vita Apollonii ('Life of Apollonius of Tyana'). ${ }^{8}$ Both the Heroikos and this particular section of the $V A$, wherein the protagonist, Apollonius of Tyana, speaks with the ghost of Achilles, contain lengthy mentions of the Homeric hero Palamedes, thus offering a common heroic figure from which Philostratus begins his defence of Greek belief.

\section{The Age of Philostratus}

Philostratus was a Roman citizen and member of the senatorial élite through his marriage to a woman named Aurelia Melitine. ${ }^{9}$ He was, however, Greek by birth and had experienced an education that had thoroughly immersed him in the history, culture and achievements of the Hellenes. Although concerned primarily with Greek tradition and religious belief, Philostratus was still working within the boundaries of Latin culture and the Roman Empire, of which Greece had been part for several centuries. The combination of Greek and Roman influences upon his life forged in him a highly dualistic view of the Mediterranean world, with his affiliation to the centre of Roman power - through the senatorial élite and his patroness, the Empress Julia Domna - perhaps drawing him from his Hellenic roots, and yet simultaneously shaping in him a distinctly Hellenistic socio-political outlook. For Philostratus, this pro-Hellenic identity was to be grounded in the poetic works of Homer. ${ }^{10}$

\footnotetext{
8 The Vita Apollonii, which tells the tale of the legendary Pythagorean preacher, Apollonius of Tyana, became something of a rallying point for many pagans facing the onward march of a progressively more powerful Christianity, so much so that the church historian, Eusebius, felt it important to refute many of its claims in his Contra Hieroclem.

${ }^{9}$ One of the couple's sons even became a senator (Swain 1991:152).

${ }^{10}$ Mestre 2004:131.
} 
The 'sophists' of the 3rd century were an important part of the struggle for Greek identity. Like Philostratus, they began their search for new forms of authority by returning to the glorious Hellenic past, ${ }^{11}$ beginning with Homer, and by asserting a desire for linguistic purity in the form of the old Athenian Attic dialect of Greek, which Philostratus also favoured. ${ }^{12}$ Add to this the fact that the popular base of this conflict was firmly held by the koine $\bar{e}$ a linguistic form mingling both Latin and Greek in common usage, and a situation emerged in which the average person sought a utilitarian language for their everyday needs, while the educated élite spoke and wrote in a different manner that exemplified their learned status, isolated them from the common man and functioned as a protest against their enforced irrelevance in a world dominated by the seemingly 'inferior' culture of Rome. Given these struggles for identity, 'Greekness' was a concept that was constantly being renegotiated within the context of the Roman Empire, ${ }^{13}$ with the pan-Hellenic relevance and reinterpretation of the works of Homer forming a battleground for this conflict, as the subject matter of the Heroikos indicates.

As Philostratus' first complete foray into a deeply religious subject, the Heroikos evolves from this time of negotiated 'Greekness'. His dialogue sets the groundwork for an emphasis on traditional religious practices that is continue in his magnum opus, the Vita Apollonii. There is some controversy as to the dating of the Heroikos, with most scholars positioning the work's terminus post quem between 217 and $220 \mathrm{CE} .{ }^{14}$ For the purposes of this argument, the most useful

11 Swain 1996:7. Conversely, Bowie 1970:40-41 believes that some Greeks would emphasise their people's prior achievements 'as an alternative to rather than an explicit reflection on the present'.

12 A good gauge of Philostratus' enthusiasm for Attic Greek can be seen in the protagonist of the Vita Apollonii, the philosopher-sage Apollonius of Tyana. Philostratus portrays Apollonius as being the paragon of 'Greekness', and the first way in which he illustrates this fact is by having him speak in perfect and unaccented Attic Greek (Philostr. VA 1.7.1). Conversely, writers from the Eastern Roman Empire favoured the more florid style of prose referred to as Asianist. The seminal work on this linguistic struggle is Wilhelm Schmid's Der Atticismus in seinen Hauptvertretern (1887).

${ }^{13}$ Swain 1996:7.

${ }^{14}$ Philostratus (Her. 14.4-15.10) mentions the visit of an athlete named Helix to the sanctuary of Protesilaos. Dio (80.10.2) provides the man's full name as Aurelius Helix, describing him as an outstanding sporting competitor. In his version of the translation of Dio, Earnest Cary 1969 proffers the belief that Helix's victory at the Olympics can be dated to approximately 219-220 CE, which places the Heroikos in the same period. Jones 2001:143 counters that 217 is a more reasonable terminus post quem for the work, arguing that Helix's Olympic victories were most likely when the competition was held in the years 213 and 217 respectively. Lane Fox 1987:144 shares Jones' perspective, as does Bowie 2011. 
comment on its probable date of publication is provided by Jones, who suggests that 'the dramatic date must be roughly "the present"; that is he [Philostratus] does not differentiate that date from the time of composition and of first publication. $^{, 15}$

The dialogue is thus set within the lifetime of its author, a rather peculiar time for the Roman Empire; the emperor Caracalla was succeeded by Elagabalus in 218, with both being non-Italian, and both bringing divergent religious policies to the Empire - Caracalla displayed an obsession with Alexander the Great (Dio Cass. 78.7.1), while Elagabalus elevated deus sol invictus to the status of chief deity (Her. 5.7). Thus in reality, the extant religious practices of the Empire were being shaken at their very core by those meant to preserve them. A third Syrian, Alexander Severus, then replaced Elagabalus upon his assassination. ${ }^{16}$ The social, political and religious atmosphere of the first quarter of the 3rd century can therefore be seen to make an important contribution to the literary form and subject of the Heroikos, especially considering that Philostratus advances the work as a 'true' story from the very mouth of the long-dead hero Protesilaos, a literary technique seen in the diaries of Dictys (1.13), who employs Odysseus to authenticate his own perspective on the Trojan War. ${ }^{17}$ When the dialogue's contemporary setting is considered alongside Philostratus' act of appropriating the 'truth' for his own ends through claiming Protesilaos as a unique and privileged source of information, one could suggest that Philostratus desires to propagate his own version of myth as a new truth, ${ }^{18}$ in order to mount a defence of the socio-religious circumstances being experienced within the Roman Empire. ${ }^{19}$ Anderson argues that evidence is lacking for any enthusiasm for the rites of the hero-cult on the part of Philostratus. ${ }^{20}$ However, when the views advanced through the persona of Apollonius of Tyana and the ghostly Achilles are assessed alongside the perspective of the Heroikos, a certain zeal for religious reinvention becomes apparent. This position is furthermore in keeping with arguments advanced by Eitrem and Mantero, both of whom suggest that Philostratus is making a concerted effort through the Heroikos to foreground the worship of the Greek heroes. ${ }^{21}$ The goal of the final portion of this discussion is to unite these views seen in Achilles and Apollonius with those revealed by Philostratus in the Heroikos in an effort to present a more comprehensive

\footnotetext{
${ }^{15}$ Jones 2001:143.

${ }^{16}$ Ball 2001:415.

${ }^{17}$ Aitken 2001:132-13.

${ }^{18}$ Bowie 1994:185.

${ }^{19}$ Pache 2004:5.

${ }^{20}$ Anderson 1986:247-48.

${ }^{21}$ Eitrem 1929:1-56; Mantero 1966:12-13, 18.
} 
picture of Philostratus' ideological repositioning of the hero-cult. What follows next, however, is an outline of the phenomenon of the hero-cult and its place in the worship of the Greek world.

\section{An argument from the foundations of the hero-cult}

Philostratus' efforts can only be understood within the broader context of the ancient hero-cult in the Mediterranean world. Archaeological evidence for the worship of 'heroes' exists as early as the first millennium $\mathrm{BCE},{ }^{22}$ with the cult remaining popular throughout the Hellenistic period, until its demise in the mid-third century CE. ${ }^{23}$ Thus, it appears, the practice of deifying heroes declined progressively before the advance of Christianity, the growing popularity of the alternative Eastern religions, and the disinterest of a population with increasingly diverse religious tastes. ${ }^{24}$ As a form of belief, however, hero-cult was essential to the earliest foundations of Greek identity, particularly as regards notions of autochthony. Moreover, Nagy writes that 'mysticism is a fundamental aspect of ancient Greek hero cults, ${ }^{25}$ meaning that, in simple terms, the same 'mystery' which surrounded the newer alternative religions, making them intriguing to the uninitiated inhabitants of the Mediterranean, could also be utilised to encourage the worship of the ancient heroes because of a similar connection with $\tau \varepsilon \lambda \varepsilon \tau a i$ sercretive ceremonies and initiation rituals. ${ }^{26}$

As one of the building blocks of Greek religious belief, the hero-cult, like the original Olympian deities, traces its roots back to the canonical myths of ancient Greece. The ancestral traditions of the cult afford Philostratus the opportunity of drawing on examples from Greece's golden age, a time immortalised by the achievements of figures like Achilles, Protesilaos and Palamedes - the heroic trio which Philostratus uses in the Heroikos and VA. A cognate of the hero-cult was the cult of the dead, an 'aristocratic ${ }^{27}$ ritual practice concerned with the propitiation of the deceased family members of worshippers in much the same way as the hero-cult centred on the worship of specific deceased heroes who

\footnotetext{
${ }^{22}$ Dué \& Nagy 2004:52.

23 Jones 2001:146. The last remnant of the cult dates to $242 \mathrm{CE}$, when a decree from Arcesine on Amorgos declared that a certain Aurelius Octavius was 'holy and decent'

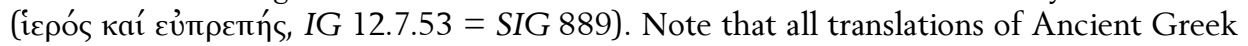
and Latin are my own unless otherwise indicated.

${ }^{24}$ Woolf 1997:80 suggests that at this time many of the great pagan festivals were actually being used as a means of creating interest in Olympian rites rather than proclaiming their importance.

${ }^{25}$ Nagy 2001:xvi.

${ }^{26}$ Follet 2004:230.

${ }^{27}$ Burkert 1985:205.
} 
were deemed to be more influential than mere relatives. Philostratus can be seen to utilise these earliest underpinnings of the hero-cult not only to comment on what he perceived as the marginalisation of traditional polis-religion in the $3 \mathrm{rd}$ century, but also to point the way to a local and Hellenic alternative to the beliefs of the East.

Walter Burkert defines a hero as 'a deceased person who exerts from his grave a power for good or evil and who demands appropriate honour. ${ }^{, 2}$ In Homer's Iliad the designation 'hero' has much to do with a person's martial prowess, while Pindar (Pyth. 4.21-61, 254-61) later suggests that extreme patriotism or religious piety as in the case of Battos, was equally likely to win one heroic honours. ${ }^{29}$ Two brief examples serve to illustrate the Homeric use of the term as it differentiates the hero and a normal human being: firstly, Homer (Il. 12.381-83) describes the Telamonian Aias killing a Trojan with a massive stone, and secondly, at Il. 20.286-87, Aeneas is depicted as raising up an immense stone. ${ }^{30}$ In both cases, the important phrase to be derived from these

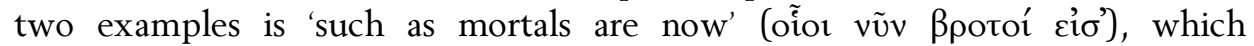
distinguishes the capabilities of the hero from more normal men and women. It is therefore apparent that, while alive, the hero was able to accomplish feats beyond the capacity of normal human beings. Similarly, Hesiod (Op. 159-60) differentiates the hero from a mere mortal by characterising the generation of

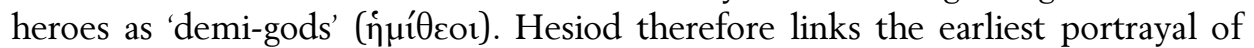
the ancient hero with the divine by suggesting that heroes are almost gods themselves. In conclusion, then, the Greek heroes are part god and part mortal, 'demi-gods' who accomplished great deeds that set them apart from humans in life. Furthermore, Hesiod (Op. 170-73) notes that heroes do not share the afterlife of mortals, as they go to live happily on the Islands of the Blessed instead of descending to Hades. ${ }^{31}$ Being í $\mu^{\prime} \theta \varepsilon$ cor they cannot ascend to Olympus either (only Herakles transcended this boundary). This indicates that heroes

\footnotetext{
${ }^{28}$ Burkert 1985:203.

${ }^{29}$ Jones 2010:11.

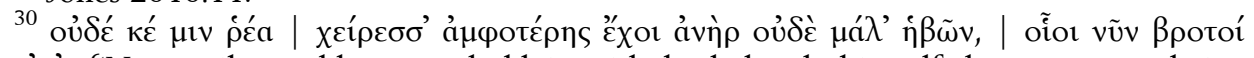
हi $\sigma$ '. ('Not easily could a man hold it with both hands himself, by no means being

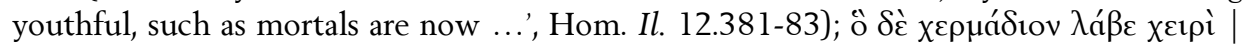

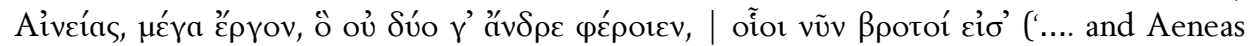
took a throwing stone in his hand - a great work - which could not be carried by two men, such as mortals are now ..., Hom. Il. 20.286-87).

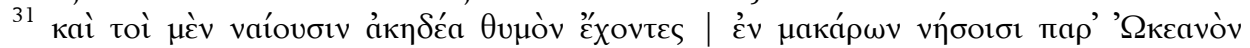

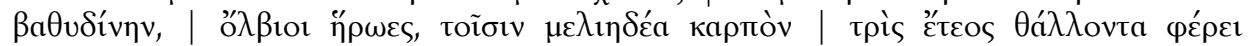

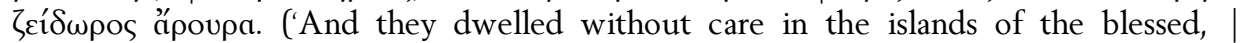
alongside deep-eddying Okeanos, happy heroes, | for them the bountiful soil bears honey-sweet fruit | flourishing three times a year.').
} 
formed a distinct category of their own, a belief further illustrated by Arrian (Peripl. M. Eux. 21) in his version of the death of Achilles, which has Thetis, Achilles' mother, snatching him off his own burning funeral pyre. She leaves him on Leukē, the White Island, ${ }^{32}$ where he is made immortal - he does not die like a mortal, nor does he ascend to Olympus. From this, it is clear that heroes assumed a unique position in Greek theology, apart from both the divine and mortal realms. And, what is more, this geographically delimited sphere of influence plays a key role in demarcating the power and authority of the herocult in general. While the belief in heroes may have transcended the geographical boundaries of the Greek world, a specific hero's influence did not - 'a hero is always confined to a specific locality: he acts in the vicinity of his grave for his family, group or city. ${ }^{33}$ Indeed it is most often around the supposed tomb or interred remains of a hero that any cult worship first develops. ${ }^{34}$ Burkert, however, contrasts the rituals of the hero-cult and the related cult of the dead, noting that the latter assumes 'the deceased is present and active' at the grave site, with worship, blood sacrifice and libations ensuring their good favour. ${ }^{35}$ Burkert goes on to compare this with the elements involved in hero-cult practices - 'blood sacrifices, food offerings, and libations ... weeping and lamentation are frequently attested', ${ }^{36}$ rituals that, given the central place of the hero's grave in the cult, firmly establish it as chthonic in origin, a ritual focus the herocult shares with the cult of the dead. Betz comments that 'hero cults are all grave cults, and where there is no grave, a hero cult is hardly conceivable. ${ }^{37}$ Here the shared chthonic nature of both the cult of the dead and the hero-cult is made apparent, as is the link between hero-cults and their respective hero's grave sites. However, the wider basis of participation (i.e. the inhabitants of an entire city or region) in hero-cults tends to make them more stable, while a cult devoted to a family's deceased members will usually die out with their memory.

The beliefs of the hero-cult are thus intimately bound up in Homeric epic, making the question of whether the cult's rituals derived from the epics or vice versa a highly significant and complicated one. Interpreting the myth of Jason

32 The White Island on which Achilles resides is situated in the Black Sea, and like Achilles himself, the island appears to have held great Pan-Hellenic significance. The archaeological record of Leukē includes a statue (c. 4th century BCE) with an Olbian decree, honouring a man who rid the area of pirates. Also discovered were a number of coins minted at various locations across the Mediterranean world. Cf. Hedreen 1991:321-22.

${ }^{33}$ Burkert 1985:206.

${ }^{34}$ Coldstream, 1976:8-9.

${ }^{35}$ Burkert 1985:194-95.

${ }^{36}$ Burkert 1985:205.

${ }^{37}$ Betz 2004:46. 
and Hypsipyle, Burkert comes to this conclusion: 'the rituals did not enact the myth, the myth did not receive its plot from the rituals. ${ }^{38}$ From this point of view it would seem that neither myth nor ritual is completely responsible for the evolution of the hero-cult, but rather that it is a symbiotic relationship. This relationship between myth and ritual leads Coldstream to argue that the ideals portrayed in the epic poems forged a new understanding of the manner in which the people of Greece related to their history, ${ }^{39}$ exalting the heroic past over the contemporary age. Furthermore, the symbiotic nature of these interrelations extends to the later development of the rituals of the hero-cult as well, with both rituals and their attendant myths contributing to the expansion of the cultic tradition. The performance of the rites of the hero-cult provides cult worship with a highly explicit emphasis and focus, turning acts of propitiation toward a single more powerful and influential ancestor who may not necessarily have been a blood relative of the worshipper in question. In all, this particular conglomeration of belief and praxis distinguishes the chthonic hero-cult from the Olympian religious tradition as a system that provides Philostratus with a platform from which to launch not only a renewal of Greek religion, but a battle against foreign beliefs as well.

Turning to the particulars of the relationship between worshipper and hero, Pache contends that this interaction is an 'individual' one, predicated upon the belief in the 'physical reality of the hero's presence, ${ }^{40}$ a physical immanence that is linked with the belief in the hero's power being strongest at his shrine or grave site. Cult rituals bound worshipper to hero in a similar manner to the individually focused religious experience that attracted worshippers to the Eastern alternative religions, wherein the participant thought himself or herself privy to an exclusive revelation, as for example was the case with the originally Persian god, Mithras. ${ }^{41}$ Liebeschuetz notes that these cults would 'dominate' the lives of their adherents, but most importantly, in his example of the cult of Isis, he goes on to state that people joined this Egyptian cult in order 'to satisfy their individual religious needs, ${ }^{, 4}$ as opposed to enacting the Olympian rites of polisreligion. Finally, it appears that in the Greek East it was, in fact, Roman imperialism that had left the polis-religion system weakened, perhaps facilitating the infiltration of religious alternatives. In this case, not every citizen agreed with the perspective of the polis-religion paradigm that marked these alternatives as

\footnotetext{
${ }^{38}$ Burkert 2004:101.

${ }^{39}$ Coldstream 1977:9-14.

${ }^{40}$ Pache 2004:9.

${ }^{41}$ Burkert 1987:45.

${ }^{42}$ Liebeschuetz 1979:222 (emphasis added).
} 
'secondary' or less than Olympian worship. ${ }^{43}$ It is here that Gordon sees Rome intentionally forcing polis-religion into conflict with alternative religions across the Empire in an effort to strengthen élite authority, Romanise key beliefs and marginalise any potentially deviant practices as superstitio. ${ }^{44}$ Philostratus' selection of the hero-cult can perhaps be seen to follow a similar tack in declaring the veracity of belief in heroes as the true and worthy replacement of the practices of polis-religion.

It must, however, be noted that traditional Olympian religion was no less integral in the lives of its believers than the Eastern alternatives. After all, sacrifice and prayer were an essential part of the daily routine of almost every home in the Mediterranean world - a part of the universal religious complex that Faraone characterises as the smallest of a series of nested religious communities'. ${ }^{45}$ It is the focal point of these two systems that is different, with Olympian rites concentrating on the well-being of the community and the newer alternatives being concerned with the religious life of the individual. Although the Severan dynasty may have largely failed in its own attempts at renewing belief in the Olympian deities, ${ }^{46}$ the populace could turn to other 'still vibrant spheres of religious life, ${ }^{47}$ of which the hero-cult was a highly popular element. According to Betz, everyone could approach the heroes at their cult shrines, and they could be 'experienced by all human beings', ${ }^{48}$ while the Olympian deities could be considered to possess an almost nationalistic character that was maintained by the local élite, a perspective that established a natural tension between public, communal worship and more individual cult activities.

In a project based at the University of Erfurt's Max Weber Centre, Jörg Rüpke and others have proposed a programme of research, concentrating on the concept of 'lived ancient religion', which, among other objectives, seeks to redress the historical imbalance in modern approaches to ancient belief that the public/civic versus cultic/private dichotomy has created. ${ }^{49}$ Their concept 'focuses on the actual everyday experience, on practices, expressions, and interactions that could be related to "religion", 50 and is thus truly an attempt at assessing the religion of the ancient individual, a phenomenon referred to by Festugière as 'personal religion. ${ }^{51}$ While he is to a certain extent correct in his

\footnotetext{
${ }^{43}$ Woolf 1997:80.

${ }^{44}$ Gordon 1990:235-55.

${ }^{45}$ Faraone 2008:222.

${ }^{46}$ Wilamowitz-Moellendorff 1959:511-13.

${ }^{47}$ Betz 2004:28.

${ }^{48}$ Betz 2004:28

${ }^{49}$ Rüpke 2012:1-5.

${ }^{50}$ Rüpke 2012:6.

${ }^{51}$ Festugière 1954.
} 
nationalistic portrayal of Greek religion when he states that, figuratively speaking, 'Athena was the goddess of Athens, of the Athenians considered as a social entity, before being the goddess of the Athenian as a private individual, ${ }^{52}$ the general tenor of Father Festugière's arguments concerning any potential divide between civic and 'personal' cult is unfortunately deeply Christian and monotheistic in emphasis, giving too great an importance to the place of the patron deity of a city over the other Olympians. While it is true that a goddess like Athene received special cult worship in the context of the city of Athens because of her role as its patroness, this was never to the exclusion of the other gods. Polis-religion was, in this case, 'one among several ordering principles' of belief, ${ }^{53}$ a means of connecting the Greek deities rather than arranging them in a hierarchy. Nor does Festugière's use of Euripides' Hippolytus provide a sufficiently powerful example to justify his case for the existence of individualised religious practices within the context of the polis-religion paradigm. Festugière's highly romanticised notion of the relationship between Hippolytus and the goddess Artemis as being akin to that of a mediaeval knight and his lady ${ }^{54}$ again Christianises what is an otherwise pagan bond between a deity and her chosen - a relationship reaching back to the constant guidance Athene granted to Odysseus as he struggled to return home (cf. Hom. Od. 7.22-23, in which Odysseus asks Athene, who wears the guise of a young woman, to lead him to the palace of Alkinoös).

It is thus the individualised perspective of the hero-cult that differentiates it sufficiently from the extant Olympian polis-religion paradigm, which can be seen as affording Philostratus the opportunity of positioning it as the logical counterbalance to the intrusion of Eastern religious rites, because the hero-cult offers the possibility of a similar individual religious experience while simultaneously granting a higher status to a traditional form of Greek religion. In addition, the fact that the heroes were bound to their bloodlines and homelands recognises Greek claims of autochthony as made manifest in the geographically delimited 'presence' of the hero, thereby affirming the socio-political and religious authority of the group ${ }^{55}$ and homogenising local belief systems and political allegiances ${ }^{56}$ in the face of external interference. In conclusion, this notion of religion as being 'homologous' with both the social and political elements of a society is also key to the polis-religion paradigm, ${ }^{57}$ marking the

\footnotetext{
${ }^{52}$ Festugière 1954:6.

${ }^{53}$ Woolf 1997:72. Cf. Sourvinou-Inwood 1990.

${ }^{54}$ Festugière 1954:15.

${ }^{55}$ Burkert 1985:190-91.

${ }^{56}$ Whitely 1988:178-80.

${ }^{57}$ Woolf 1997:73-74.
} 
hero-cult as an appropriate direction in which to channel Greek religious belief. In this way, the Philostratean deployment of the hero-cult through the Heroikos can be seen as an attempt at formulating a viable alternative to the spread of Eastern alternative religions by reinvigorating an ancient tradition that would provide people with a universally understood belief system. The specifics of this programme of reinvigoration will be demonstrated in the following section.

\section{The Heroikos and the defence of Greek piety}

The Heroikos is written as a dialogue between the two characters of a vinedresser and a Phoenician merchant, with the vinedresser gradually revealing knowledge of the hero Protesilaos to the sceptical Phoenician until he, too, reaches a point of complete faith in the hero. The merchant arrives at the

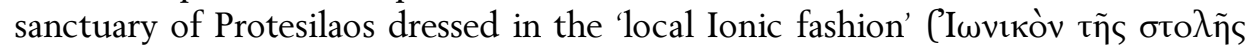
Ėrıxúpıov, Her. 1.1), an example of the self-indulgent luxury that Greeks believed was characteristic of all foreigners. ${ }^{58}$ The presence of the Phoenician reflects the socio-religious reality of Philostratus' time through a character emblematic of all foreigners who chose to dwell within the borders of the Roman Empire and yet maintained the lifestyle and religious traditions of their homelands. ${ }^{59}$ This preference for native custom influenced the development of a highly syncretic religious perspective as exemplified in the practices of Emperor Elagabalus, ${ }^{60}$ but simultaneously also calls attention to the fact that many foreigners held positions of power in imperial Rome. ${ }^{61}$ With foreigners exercising growing influence within the cities of the Empire, the religious status quo began to shift. An increasing number of foreign residents meant that it became more difficult for social order to be imposed through the unifying belief of the polis-religion paradigm, with fewer people participating in the major opportunities for Olympian worship. ${ }^{62}$ This indicated that another means was necessary to unite the Greek people, and for Philostratus that paradigm was to be found in the cult of heroes.

Despite their having been members of the Roman imperial family for some years, ${ }^{63}$ Phoenicians were still thought of as 'other ${ }^{64}$ - given to luxury and moral dissipation. From a literary perspective, the Phoenician can also represent the

\footnotetext{
${ }^{58}$ Maclean 2004:254.

${ }^{59}$ Maclean 2004:256-57.

${ }^{60}$ Maclean \& Aitken 2002:lxxviii-lxxix.

${ }^{61}$ Maclean \& Aitken 2002:1xxix.

${ }^{62}$ Woolf 1997:79.

${ }^{63}$ Aitken 2004:278-79.

${ }^{64}$ Cf. Bowersock 1969:108.
} 
journey of the reader, as he participates in five identifiable aĩvor over the course of the Heroikos, unique speech acts that frame the character's progress towards religious enlightenment as a follower of Protesilaos. ${ }^{65}$ These speech acts are aimed at a particular audience as well, namely 'those who are skilled (бофós) in interpreting the coded message [i.e. the aîvor themselves], ethically noble

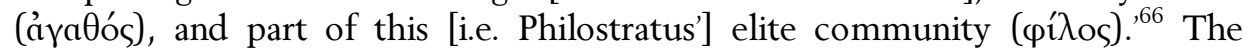
aivor also function as a set of proofs, serving the dual purpose of teaching the Phoenician of the hero Protesilaos and exposing the reader to similar knowledge as well. Finally, Philostratus can be argued to cast his Phoenician character in the role of a 'doubting Thomas', whose gradual coming to belief illustrates the potential revivification of the cult of Protesilaos and of the hero-cult as a whole. Christian echoes are evident in the Philostratean language describing this

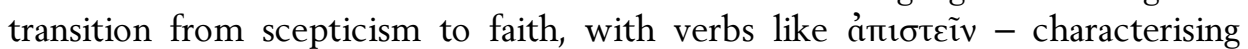
scepticism or a lack of belief - mirroring the language of the New Testament:

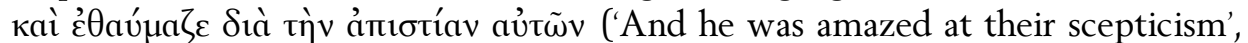

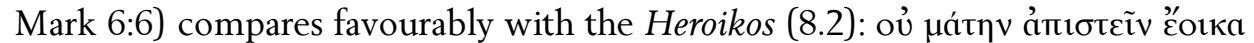

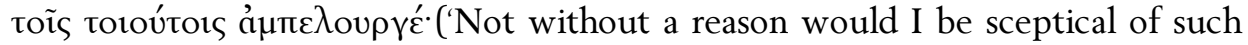
things, vinedresser ...'). Likewise, Betz identifies the Philostratean use of $\pi \imath \tau \tau \varepsilon \dot{v}-$ $\varepsilon ı v$ - to have faith or belief - as being analogous with Christian uses. ${ }^{67}$

Even the relationship between hero and worshipper - Protesilaos and vinedresser - is couched in the language of the Eastern alternative religions, with the hero personally teaching the vinedresser in what could be characterised as Guvouría (a 'being together' or 'communion', Her. 7.3), very much like the 'intimate relationship' shared by Jesus of Nazareth and his own apostles. ${ }^{68}$ This intimate bond is also an essential element of the broader Greek hero-cult ${ }^{69}$ which Philostratus can be said to point out in delineating his character of the vinedresser. ${ }^{70}$ The vinedresser therefore sources his information regarding the veracity of his cult's rituals and the heroic tradition itself from the actual hero in question. In addition, this same intimacy was extended to all worshippers in the

\footnotetext{
${ }^{65}$ Maclean 2004:257.

${ }^{66}$ Maclean 2004:257.

${ }^{67}$ Betz 2004:29 nn. 25, 26.

${ }^{68}$ Maclean 2004:212. This is indicative of the fact that, although never stated directly, Philostratus appears to have knowledge of the Christian cult (Betz 2004:26).

${ }^{69}$ Maclean 2004:212. Both the hero-cult and early Christianity share an intimate form of greeting, an embrace or kiss between followers or between hero and worshipper (cf. Her. $11.2 ; 21.6$; 51.13). Christians are likewise exhorted to greet one another with a

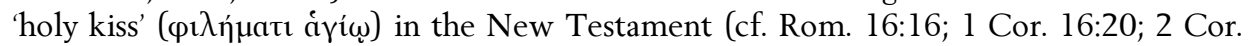
13:12; 1 Thess. 5:26). See also Betz 2004:34 n. 37.

70 The question of the 'value of immediate experience of the divine world' was common to both the hero-cult and early Christianity (Maclean \& Aitken 2002:1xx-lxxi).
} 
case of the alternative Eastern religions, with rich and poor alike sharing a similar status as believers. ${ }^{71}$ Nowhere is this more clearly expressed than in Jesus'

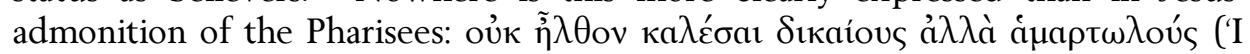
did not come to call the just, but sinners', Mark 2:17). Such sentiment clearly upends the social organisation articulated within the context of the polis-religion paradigm which gave public cult a central role, with those same cults being controlled by the city's élite, educated and powerful. ${ }^{72}$

Choosing to label the character as a vinedresser allows Philostratus to suggest that he is not only responsible for the physical well-being of the cult sanctuary, but is in a metaphorical sense responsible for cultivating belief in the cult of Protesilaos as well. ${ }^{73}$ This agricultural metaphor again mirrors a similar depiction that the Gospel of John (John 15:5) employs of the early Christian cult, whereby Jesus declares himself to be the Christian vine (á $\mu \pi \varepsilon \lambda$ os) with his believers its branches. Continuing this metaphor, Philostratus characterises the hero Protesilaos as both a 'farmer' and a 'gardener' (Her. 11.2; 21.6; 51.13), again paralleling the Johannine gospel (John 20:14-18) where Jesus, following his resurrection, is mistaken for a gardener by Mary Magdalene. ${ }^{74}$

As a Philostratean character, the vinedresser presents a number of important qualities - from his choice of a simple lifestyle to the linguistic flair of a true Atticist - which shape him as 'the perfect spokesman for the literary, religious, and moral superiority of the world of the Greek heroes'. ${ }^{75}$ The tale of the vinedresser's former life also presents a moral of its own for readers: he was once wealthy and owned property in the country. While studying philosophy in the city he was swindled out of his money and property. He prayed to Protesilaos, who was initially annoyed at the vinedresser's presumption (having not worshipped him previously), but was finally won over and granted him an oracle, which the vinedresser took to mean that he should change his lifestyle. It was then that he moved to the sanctuary of Protesilaos and began his new life in service of the hero (Her. 4.9-10). Lastly, the vinedresser and the Phoenician are also generalised figures who cannot be immediately connected with any historical personage, despite the dramatic setting of the work being the author's own era. This can

\footnotetext{
${ }^{71}$ Woolf 1997:79.

${ }^{72}$ Woolf 1997:72.

${ }^{73}$ Maclean \& Aitken 2002:xliii n. 1.

${ }^{74}$ An additional point of convergence is to be found in the sharing of a meal, almost always an element of hero-cult practice (Burkert 1985:205). Both the hero Protesilaos and the risen Jesus are shown to refrain from eating or drinking, (the vinedresser comments that he has never seen Protesilaos eat or drink, Her. 11.9), while Jesus accompanies two of his followers to Emmaus, breaks bread with them and then vanishes (Luke 24:30-35).

${ }^{75}$ Rusten 2004:143-44.
} 
potentially be viewed as an attempt at broadening the appeal of Philostratus' message beyond the educated élite.

The manner in which Philostratus establishes his characters points to an attempted juxtaposition of the Greek hero-cult with alternative Eastern religions such as early Christianity, particularly through Philostratus' description of a 'personal conversion experience' as perhaps being responsible for bringing the vinedresser to the cult of Protesilaos. ${ }^{76}$ The relationship that the vinedresser has with Protesilaos can be viewed as illustrating the direction in which Philostratus would like to advance his reformed tradition of hero worship through the offering of an encounter with the Greek heroes that had the potential to emulate the experience initiates had of the various alternative Eastern rites, be it the worship of the Syrian goddess or Jesus Christ. Philostratus further utilises his description of the physical shrine of Protesilaos as a means of emphasising the enduring popularity of the hero-cult through the fact that the statue of Protesilaos has been worn down by people repeatedly touching it when they make vows (Her. 9.1-7). The setting and background of the Heroikos are thus rendered in a manner that shows Philostratus to be inventing a new tradition that is removed from the Homeric canon with which the work claims its initial affinity ${ }^{77}$ while at the same time seeking to retain the cult's roots within Hellenic soil. Philostratus' reworking of Homer may therefore be seen as a case of Protesilaos functioning as a nexus for local traditional authority, creating a counterpoint to the established and pan-Hellenic 'official version of events' that the Homeric epics represented. ${ }^{78}$

Alcock describes a similar situation as seen in the context of other localised religious traditions, where three heroic sanctuaries - the Agamemnoneion near Mycenae, the Polis Cave on Ithaca, and the Menelaion in Laconia - all experienced a religious resurgence of sorts during the Hellenistic period, only to be abandoned sometime between the lst century BCE and the 1st century CE. ${ }^{79}$ Alcock goes on to argue that the hero-cult rites performed at these sanctuaries did not simply end, but were instead transferred and 'concentrated within more central, or more accessible places', where the rites could be more easily controlled by the local élite and so utilised as a form of 'social power' that emphasised the importance of local tradition over more broadly Hellenic rites. ${ }^{80}$

76 Betz 2004:31. It is almost a Damascene conversion experience which sees the vinedresser completely abandon his old life for a new life in the cult of Protesilaos (cf. Acts 9:1-19).

${ }^{77}$ Bowie 1994:184.

${ }^{78}$ Maclean \& Aitken 2001:1xxxi.

${ }^{79}$ Alcock 2004:163-64.

${ }^{80}$ Alcock 2004:167. 
This enabled the concentration of the religious sentiments of the people in a manner that made them look inward at their own history, culture and beliefs, rather than outward for novel and foreign approaches to the divine. The Heroikos can be argued to have been positioned in the very same way - a dialogue that speaks directly to the aristocratic actors to whom control of the cult of heroes fell, ${ }^{81}$ exhorting them to re-emphasise local religious ideologies over the newer Eastern alternatives.

\section{Protesilaos as Philostratus reinvents him}

An assessment of Philostratus' (Her. 10.2-3) approach to the cult of Protesilaos should begin with his statuesque description of the hero himself:

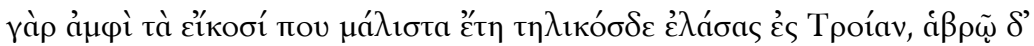

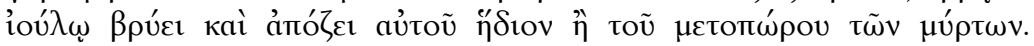

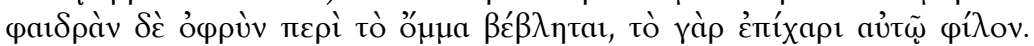

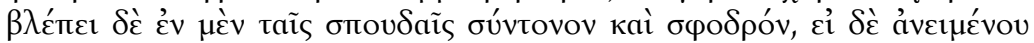

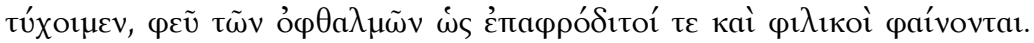

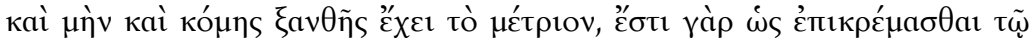

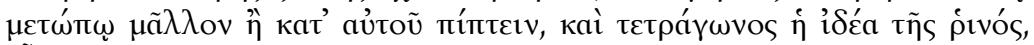
oĩov ảyá $\mu$ utos.

For he is around twenty years old at most, having sailed for Troy at such a young age, he has a full and luxurious beard and smells sweeter than autumn myrtles. Joyful eyebrows are thrown up around his eyes, for he has a friendly, pleasing demeanour. In action he looks intense and zealous, but if we should happen upon him when relaxing, oh how lovely and friendly his eyes appear. And what is more he has blonde hair of moderate length, for it hangs over his forehead rather than falling upon it, and the form of his nose is squared, like a statue's. ${ }^{82}$

Philostratus is thus highly specific in his detailed description of Protesilaos, a hero to whom Homer (Il. 2.695-710) devotes little more than fifteen lines. ${ }^{83}$

\footnotetext{
${ }^{81}$ Alcock 2004:165.

${ }^{82}$ Although translations of the text of the Heroikos are my own, it should be noted that they are based upon the work of Maclean \& Aitken 2001, 2002.

${ }^{83}$ Although his time in the Iliad is brief, archaeological evidence suggests that Protesilaos was popular throughout much of antiquity, with the worn state of his cult statue (Her. 9.1-7) pointing to Philostratus' awareness of this fact. The statue in the possession of the Metropolitan Museum is believed to be a copy of the cult statue from his sanctuary at Elaious (Follet 2004:231; cf. Richter 1929:187-200). Protesilaos appears on coins from Skionè to Thessaly to Elaious itself, dating from the 5th century BCE to the 2nd century
} 
Pausanias (4.2.5) provides additional biographical details, stating that Protesilaos, son of Iphikles, was born in the town of Phulake in Thessaly. He desired to be the first Greek to attack Troy, but was slain shortly after leaping from his ship. ${ }^{84}$ Apollodorus (Epit. 3.30) explains why Protesilaos may have received heroic honours for his early exit from the Trojan War by fleshing out his last moments on the Trojan shore, and adding that Protesilaos slew many warriors single-handedly before Hektor, the greatest of the Trojans, finally killed him. ${ }^{85}$ The key element to the tale of Protesilaos appears to be his absolute commitment to the Greek cause at Troy. With the Trojan War being the quintessential conflict between the Mediterranean world and the barbaroi of the foreign East, it is the perfect point of departure for Philostratus' own struggle against foreign religions. Through the character of the vinedresser Philostratus (Her. 7.3) adds his own opinion concerning the heroisation of Protesilaos:

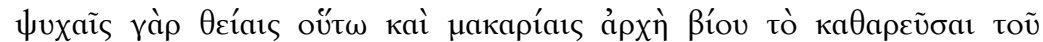

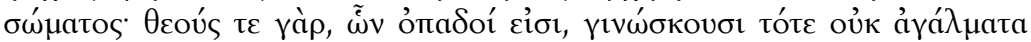

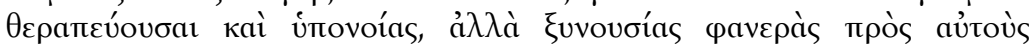
поьоúpeval ...

For such divine and blessed souls, the beginning of life is to be purified of the body; for the gods, whose attendants they are, they understand from then on, not by worshipping statues and suppositions, but by bringing about a manifest communion with them.

Philostratus' observation compares favourably with the perspective of 'mystery' cults in general, where the central revelation or 'truth' was withheld from outsiders to the cult, supposedly offering a more perfect communion with the deity for initiates alone. By receiving heroic honours, Protesilaos achieved a state of partial divinity, a closeness to the divine that is perhaps similar to that experienced by those being initiated into the alternative Eastern religions. So unlike anything was this experience that Sopater of Athens (8.115.1) describes

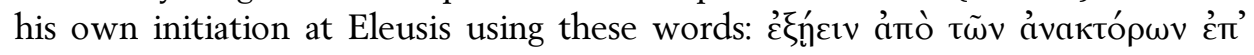

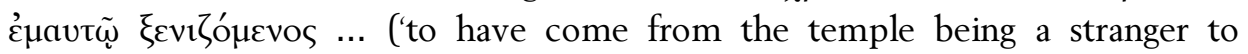
myself ...'). Thus while such a छuvovoía was not unheard of in the Greek world,

CE (cf. LIMC s.v. 'Protesilaos', no. 4-6, 10-11). Even the novelist Chariton (Callirhoe 5.10) makes mention of Protesilaos as an avenger of the Hellenes.

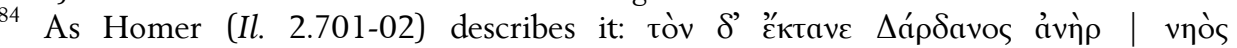

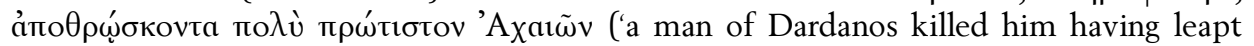
from the ship by far the first of the Achaeans').

${ }^{85}$ Known statues of Protesilaos typically depict the hero in this manner, stabbing at his enemies from the ram of his ship. Cf. Richter 1929:187-200. 
it was far more the exception than the rule, as is seen in the typical rites of Olympian worship. ${ }^{86}$ What many of the alternative religious systems therefore appeared to accomplish was granting such an experience (i.e. Guvovoía) a more central and essential place in belief, in effect potentially sidelining religious perspectives that failed to cater for such an individual practice. This was additionally an egalitarian approach which could be shared by rich and poor alike, thereby challenging the rigorous delineation of society maintained by Olympian belief. ${ }^{87}$ One could conclude from this that the symbiotic communion of which Philostratus speaks in the Heroikos is possibly his reaction to this doctrinal shift displayed by the alternative Eastern religions, and is his attempt at repositioning the hero-cult as a traditional and localised spiritual riposte against the intrusion of these rites on the Greek religious and social landscape.

Hero-cult depends on a resurrection mythos to express some of its more unusual supernatural elements. Lucian provides such a resurrection tale for Protesilaos in his Dialogues of the Dead $(25,23)$ : Protesilaos' love for his wife, Laodameia, was such that he journeyed into Hades to find her after she had died. Persephone, moved by this display, prevailed upon her husband to allow the couple to spend one more day together, after which Protesilaos returned from the world of the dead in a patently shamanic journey that transformed him, bestowing 'superhuman consciousness' upon him, along with both magical and oracular capabilities. ${ }^{88}$ This particular part of Protesilaos' mythology was in fact so well known in antiquity that early Christian authors felt obliged to counter the tale. ${ }^{89}$ Such shamanic tendencies speak to the concentration of religious authority in the hands of a few notables, as is witnessed in the transference of cultic rites from centuries-old sanctuaries to places more immediate to the cities and towns responsible for their maintenance. ${ }^{90}$ This trend was further amplified by the proliferation of itinerant holy men and women in the region, in whose presence new and unique icons of sacred behaviour became apparent. These pagan 'saints' exemplified the 'habits and expectations of a new, more intensely personal style of society', ${ }^{91}$ but were themselves set apart from society. ${ }^{92}$ It is the

\footnotetext{
${ }^{86}$ See above, pp. 87-88.

${ }^{87}$ Woolf 1997:79.

${ }^{88}$ Dué \& Nagy 2001:xxviii. See above p. 90 for the oracle that Protesilaos initially grants the vinedresser.

${ }^{89}$ Maclean \& Aitken 2002:liv. Cf. Origen, Cels. 2.55-56, where he asks why it is that Christians refuse to understand Jesus' resurrection in the same manner as the ancient Greek heroes like Protesilaos. See also Minucius Felix, Oct. 11.

${ }^{90}$ See above, p. 91.

${ }^{91}$ Brown 1971:100.

${ }^{92}$ Brown 1971:97.
} 
individuality of these 'stranger[s] par excellence ${ }^{, 93}$ that mirrors Philostratus' own intent in casting his version of the hero-cult as emanating from Protesilaos, for both occur as a result of the increasing influence of the notion that religion was a choice better left up to the individual.

Philostratus can be argued to extend the microcosmic response of his reconceived hero-cult to the macrocosm of the socio-political as well as through his selection of Protesilaos and the sanctuary at Elaious. Pausanias (1.34.2) describes the entire area around Elaious as being dedicated to the cult of Protesilaos and facing a major sanctuary of Achilles on the opposite side of the Hellespont at Sigeion. The fact that both of their tombs and sanctuaries were 'positioned on the fulcrum between East and West ${ }^{94}$ is indicative of their function of protecting all things Greek from the influence of the East, and by extension, the foreign world. ${ }^{95}$ From Philostratus' perspective, this makes it possible for these heroes to share the duty of defending the Greek world, the status of the relatively unknown Protesilaos being elevated by his geographical association with the mighty Achilles. Herodotus (7.33; 9.116-20) illustrates this defence of the Hellenic world through his tale of the Persian governor Artayctes, who controlled the province in which Protesilaos' shrine at Elaious fell. Herodotus

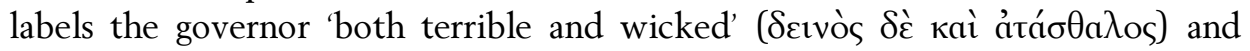
states that he committed many outrages against the shrine, including having sexual intercourse within its precincts. ${ }^{96}$ Artayctes was eventually captured by the Greeks and crucified, but only after a miraculous portent (onuaível, "he gives a sign', Hdt. 9.120.2) of some cooked fish coming back to life, that suggests a revivified Protesilaos would have his vengeance. This occurrence both exemplifies the protective power of Protesilaos in defending the integrity of Greek belief against Eastern influences, and the mystical nature of the herocult $^{97}$ which is brought back to life through the belief of the vinedresser. Herodotus adds to the mystery of this miraculous occurrence even through his choice of language, whereby his use of the ambiguous táprxos (denoting both the preserved fish of the Protesilaos tale and a 'mummy' in Egyptian stories; cf.

\footnotetext{
${ }^{93}$ Brown 1971:91.

${ }^{94}$ Whitmarsh 2004:239.

${ }^{95}$ Rahim Shayegan 2004:285-315 develops this notion of Protesilaos standing a spiritual watch in defence of the Mediterranean through the very real conflict between the Roman Empire and the Sasanians of Persia.

${ }^{96}$ Boedeker 1988:39-40 states that because of Protesilaos' separation from his wife, Laodameia, Artayctes' sexual outrages would have been highly offensive, although Boedeker does also note that scholars such as Burkert (1983:231-238, 245) suggest that these sex acts may be little more than additions to a myth designed to mirror that of the god Dionysus.

${ }_{97}$ Nagy 2001:xvii.
} 
Hdt. 2.85-89) bears a resemblance to the 'opaque language' with which he describes other mystery rites so as not to reveal their secrets. ${ }^{98}$ Herodotus' mystical description can therefore be seen to enhance Philostratus' own potential efforts at mystifying the hero-cult in response to the popularity of Eastern religious alternatives, whilst defending the integrity of Greek belief and social order. The concluding section of this article broaches the issue of the manner in which Philostratus employs Protesilaos, Achilles and Palamedes in his Heroikos and $V A$, and investigates the shared nature of their symbolic resistance to eastern incursions.

\section{Protesilaos, Achilles, Palamedes: symbols of resistance and rebirth}

The terminus post quem of the VA coincides with the death of Philostratus' patroness, the Empress Julia Domna, in $217,{ }^{99}$ and suggests that he may have worked on the $V A$ and the Heroikos at roughly the same time. But the two works have other commonalities as well, for the $V A$ and Heroikos both present similar religious and socio-political ideologies, and can be shown to attempt the reframing of the traditional perspective of the ancient hero-cult for an audience with increasingly varied religious sensibilities. His is not an exercise in reinvention for its own sake, for Philostratus can be argued to empower these popular traditions, granting them an even greater relevance in his age of disparate beliefs.

A potential catalyst in Philostratus' decision to write the Heroikos is the visit of Emperor Caracalla to the tomb of Achilles in 215 CE. The extravagance with which Caracalla carried out his cult worship perhaps made an impression upon Philostratus, ${ }^{100}$ altering the manner in which he had previously conceived of the importance of the hero-cult. After all, these rites had brought an emperor across the known world to personally see to their observance. Philostratus' decision to utilise the cult of Protesilaos also has its genesis in the fact that while much of the Graeco-Roman world still held the hero-cult in high esteem, the status of the Olympian deities had declined sharply. ${ }^{101}$ And what is more, with peripheral cult sanctuaries across the Mediterranean being merged into larger complexes in order to bring them under the direct control of the local élite, ${ }^{102}$ it is apparent

\footnotetext{
${ }^{98}$ Nagy 2001:xvii-xviii.

${ }^{99}$ The reference to Aurelius Helix (Philostr. Her. 14.4-15.10) dates this work to within a few years of the completion of the $V A$ (see above, note 14). The $V A$ was in fact commissioned by the Empress Julia Domna (Philostr. VA 1.3.1).

${ }^{100}$ Solmsen 1940:559.

${ }^{101}$ Eitrem 1929:2.

102 See above, p. 91.
} 
that the religious landscape of the Hellenic world was changing to situate centres of belief (and the influence that came with them) in more localised contexts. Philostratus' Heroikos can be seen to offer a powerful argument by way of his own peculiar brand of 'creative history' 103 that presents a means of preserving traditional beliefs via a local example of the hero-cult, while simultaneously reminding his élite fellows that it offers a viable and entirely Hellenic substitute to the allure of alternative Eastern religions.

Philostratus' emphasis on the hero-cult can be viewed as foregrounding a practice not only Greek in inception, but founded on the canon of Greek mythology and literature as well, a canon which Philostratus seems to manipulate in order to proffer a variation on Homeric legend as the basis for his renewed perspective on the hero-cult. It is thus argued that Philostratus augments the specific details of Protesilaos' existence for his own ends whilst retaining the character's place in the canon. He deploys a re-engineered mythology that permits him to refocus the religious attentions and sensibilities of his contemporaries upon the thriving hero-cult, thereby exalting an esteemed, local, religious tradition capable of providing a similar mystique to that of the Eastern alternatives. The distinction between the highly individualised perspective offered by these rites and the community-based approach inherent in the

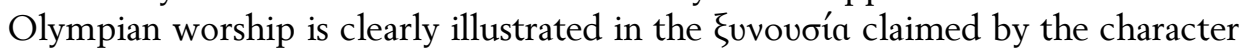
of the vinedresser, a relationship that was largely impossible within the bounds of traditional Olympian worship, given its concern for the well-being of the polis, a position that largely ignored an individual's specific needs regarding religious experience.

The Vita Apollonii accesses the authority of the hero-cult through a different hero to the Heroikos, namely Achilles, with whose ghost Apollonius of Tyana speaks (VA 4.10-16). This conversation marks what can be viewed as Philostratus' second attempt at rationalising the ancient heroic tradition ${ }^{104}$ by crafting his own variation on an Homeric theme which presents both Achilles and Protesilaos as legitimising Philostratus' own point of view. ${ }^{105}$ The pair's shared duty as protectors of the Hellenic world only serves to reinforce this. A second connection between the two works lies in their representation of Pythagorean philosophy. In the $V A$, Apollonius of Tyana is a practicing Pythagorean from the age of fifteen ( $V A$ 1.7.3) who maintains a lifestyle of preaching and teaching that marks him as the supreme Pythagorean - Maria Dzielska's

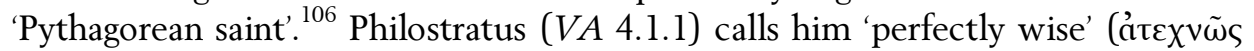

\footnotetext{
${ }^{103}$ Morgan 1982:224.

${ }^{104}$ Mestre 2004:132-33.

${ }^{105}$ Mestre 2004:132.

${ }^{106}$ Dzielska 1986:142.
} 


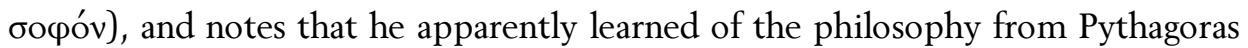
himself ( $V A$ 1.32.2), in much the same way as the vinedresser claims to have learned of the cult of Protesilaos. The literary atmosphere of the Heroikos appears suffused with Pythagorean ideals. ${ }^{107}$ The bloodless sacrifices offered by the vinedresser (Her. 11.9) point to his being a Pythagorean, ${ }^{108}$ especially when one considers that blood offerings were the expected form of sacrifice for Greek chthonic cults. ${ }^{109}$ And what is more, the vinedresser's observance of Protesilaos' initial oracle instructing him to change his lifestyle (Her. 4.9-10) is also indicative of Pythagorean tendencies as seen in Apollonius of Tyana (VA 1.13.1-2), whom Philostratus describes as giving up his wealth for the life of an itinerant philosopher. It can therefore be suggested that Philostratus' conception of the venerable origins of Pythagoreanism, ${ }^{110}$ functions as a means of binding these two works together, uniting them into a single Philostratean 'manifesto' asserting the importance of the local and the traditional in preserving Greek religious belief, with the hero-cult as archetype, thereby challenging the validity of newer Eastern alternatives.

At a time when the Roman conquest of the region had all but prevented Greeks from achieving heroisation through accomplishments on the field of battle, ${ }^{111}$ noble and statesmanlike exemplars of belief became particularly important. This form of hero aided in humanising the face of Philostratus' religious challenge through pagan 'saints' like Apollonius of Tyana and the Homeric hero, Palamedes, whom Philostratus portrays as a noble and just man of an ascetic bent (and thus Pythagorean sympathies) in both the Heroikos and $V A$. For Philostratus, Palamedes is a man of principle, fit to be emulated, ${ }^{112}$ a human example to all and not an obscure religious principle known only to a chosen few, as in the case of mystery cultism. Philostratus mentions a statue of Palamedes in the VA (4.13.3) that Apollonius of Tyana returns to its rightful station, while making this petition:

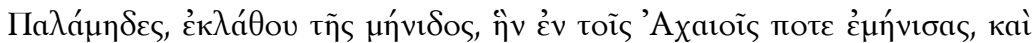

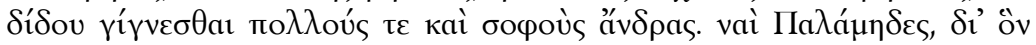

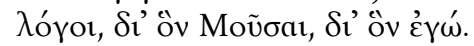

\footnotetext{
${ }^{107}$ Aitken 2001:133; Solmsen 1940:565-66.

108 The vinedresser offers sacrifices of sweetmeats, wine, and milk, but never the blood sacrifices customary for the hero-cult (Her. 11.9).

${ }^{109}$ Burkert 1985:194-95.

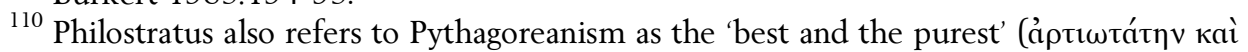

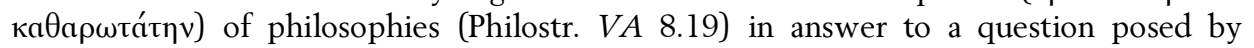
Apollonius of Tyana at the oracle of Trophonius.

11 Jones 2010:37.

${ }^{112}$ Aitken 2001:133.
} 
Palamedes, forget the wrath that at one time raged towards the Achaeans, and grant them many wise men. Yes, Palamedes, through whom there are languages, the Muses, myself.

While conversing with Apollonius of Tyana, the ghostly Achilles describes Palamedes as:

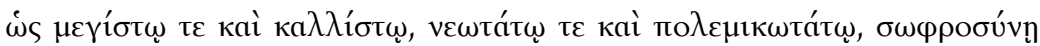

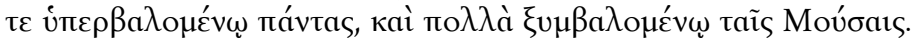

... greatest, and handsomest, youngest, and most warlike, exceeding all in temperance, and contributing many things to the Muses.

(Philostr. VA 4.16.6)

Palamedes is thus established as a clear exemplar of virtue and wisdom in the $V A$, a perspective that Philostratus brings to the Heroikos (21.1-9) with the lengthy tale concerning Palamedes that Protesilaos related to the vinedresser. This provides yet another illustration of Philostratus correcting the Homeric canon, thereby emphasising his own reinvention of this canon as the premier source of truth regarding the hero-cult because his information comes directly from the hero Protesilaos. As a previously untapped source of information, Protesilaos affords Philostratus the opportunity of casting Palamedes as a new icon of 'Greekness', ${ }^{113}$ thereby enabling him to project his own religious ideology onto Mediterranean society through this reinvention. Furthermore, while Palamedes functions to provide an exemplar for the populace to follow in their lives and religious observances, the hero Protesilaos acts to personify Philostratus' own ideological struggle against the power of foreign cult beliefs, giving a visible focus to the Philostratean defence of Greek religion, firmly embodying local tradition through the Greek hero-cult.

\section{Conclusion}

Through his carefully selected heroic trio it could be said that Philostratus reveals that his desire to ward off Eastern influences is not born solely of a greater need for physical security - with numerous conflicts developing along the Empire's borders ${ }^{114}$ - but for spiritual security as well. Given the negative connotations that Philostratus appears to ascribe to the 'un-Greek' and luxurious temptations of the East, as evinced in his portrayal of the Phoenician at the

\footnotetext{
${ }^{113}$ Mestre 2004:135.

${ }^{114}$ See Rahim Shayegan 2004:285-315.
} 
outset of the Heroikos, and as seen in his particular characterisation of Apollonius of Tyana, he could not have been impressed by the proliferation of individualised Eastern alternative religions that had begun to overwhelm the imagination of the Empire's citizenry. And what is more, the lengthy peace of the pax Romana, along with the development that it fostered, had permitted a far more rapid dissemination of nascent religious ideologies through itinerant preachers as is seen in the case of the early Christians. ${ }^{115}$ It is therefore argued that Philostratus' unique and inventive reconceptualisation of the ancient herocult enables him to deploy the cult as a metaphorical shield with which to ward off the religious exigencies of his age. ${ }^{116}$

Not only is it conceivable that Philostratus utilises the hero-cult to counteract Eastern alternatives, but through it he also proffers a powerful and enduring symbol of resurgent Hellenic tradition, after which the peoples of the Greek world are asked to model both their behaviour and belief in the face of shifting structures of faith and piety. Philostratus' juxtaposition of the heroic figures of Achilles, Protesilaos and Palamedes with the Eastern religious alternatives provides a specific local and traditional substitute for the Eastern rites' emphasis on the place of the individual believer. Given the Mediterranean world's appreciation for antique tradition, Philostratus appeals to two forms of ancient authority to define his perspective on the hero-cult, with the first being Homeric epic and the second being the Pythagorean philosophy. In this way, two ancient traditions are united in defence of traditional belief, mirrored in the vigil of Achilles and Protesilaos standing astride the Hellespont. Through the tale told by the vinedresser, Palamedes is able to unite these two heroes, becoming a shining example of belief and behaviour to the Greek people, an example that provides a local and traditional counterpoint to the influence of the alternative Eastern religions in the Greek tradition of hero worship.

\footnotetext{
${ }^{115}$ Woolf 1997:79.

116 Hilton 2012:64-65 suggests that Heliodoros' romance, the Aithiopika, might form part of the literary tradition of the Emperor Julian's pagan revival in the 4th century. With its extremely positive perspective on the myth of Neoptolemos, the son of Achilles, the work is possibly an attempt at highlighting a reinvigorated hero-cult in a manner not unlike Philostratus. Indeed, at the time of Julian, Christian veneration of the saints mirrored many of the elements of the Greek hero-cult, with some Christians even co-opting the Greek ípஸ̄ov (a hero-cult shrine) for their own tombs (Jones 2010:64). While Christianity was triumphant in the 4th century, a century earlier paganism was still very much struggling for its survival, and this is why Philostratus elects to return to the very roots of Greek belief in the hero-cult in an effort to maintain the socio-religious order of polis-religion. Much like in Julian's time of pagan revival, Philostratus sees that Christianity and the other Eastern alternatives simply share too much in common with the hero-cult for it not to be utilised as a means of struggle.
} 


\section{Bibliography}

Aitken, E.B. 2001. 'The cult of Achilles in Philostratus' Heroikos: a study in the relation of canon and ritual.' In S.R. Asirvatham, C.O. Pache \& J. Watrous (edd.), Between Magic and Religion. Interdisciplinary Studies in Ancient Mediterranean Religion and Society, 127-135. Lanham, Mass.: Rowman and Littlefield.

Aitken, E.B. 2004. 'Why a Phoenician? A proposal for the historical occasion for the Heroikos.' In Maclean \& Aitken 2004:267-284.

Alcock, S.E. 2004. 'Material witness: an archaeological context for the Heroikos.' In Maclean \& Aitken 2004:159-168.

Anderson, G. 1986. Philostratus: Biography and belles lettres in the third century. A.D. London: Croom Helm.

Anderson, G. 1993. The Second Sophistic: A Cultural Phenomenon in the Roman Empire. London: Routledge.

Ball, W. 2001. Rome in the East. The Transformation of an Empire. New York: Routledge.

Betz, H.D. 2004 [1996]. 'Hero worship and Christian beliefs: observations from the history of religion on Philostratus's Heroikos.' Transl. J.P. Hershbell. In Maclean \& Aitken 2004:25-47.

Boedeker, D. 1988. 'Protesilaos and the end of Herodotus' Histories.' ClAnt 7.1:30-48.

Bowersock, G.W. 1969. Greek Sophists in the Roman Empire. Oxford: Clarendon.

Bowie, E.L. 1970. 'Greeks and their past in the Second Sophistic.' Past and Present 46:3-41.

Bowie, E.L. 1994. 'Philostratus writer of fiction.' In J.R. Morgan \& R. Stoneman (edd.), Greek Fiction. The Greek Novel in Context, 181-199. London: Routledge.

Bowie, E.L. 2011. 'Philostratus.' Brill's New Pauly. Brill Online. Accessed 10 February 2011.

Brown, P. 1971. 'The rise and function of the holy man in Late Antiquity.' JRS 61:80-101.

Burkert, W. 1983. Homo Necans. Berkeley: University of California Press.

Burkert, W. 1985. Greek Religion. Cambridge, Mass.: Harvard University Press.

Burkert, W. 1987. Ancient Mystery Cults. Cambridge, Mass.: Harvard University Press.

Burkert, W. 2004. 'Jason, Hypsipyle and new fire at Lemnos.' In Maclean \& Aitken 2004:99-123.

Cary, E. 1969. Dio. Roman History. London: Heinemann.

Coldstream, J.N. 1976. 'Hero-cults in the age of Homer.' JHS 96:8-17. 
Coldstream, J.N. 1977. Geometric Greece. London: E. Benn.

Cumont, F. 1956 [1906]. The Oriental Religions in Roman Paganism. New York: Dover.

De Lannoy, L. 1997. 'Le problème des Philostrate (état de la question).' In H. Temporini \& W. Haase (edd.), ANRW 34.3:2362-2449. New York: De Gruyter.

Dué, C. \& Nagy, G. 2001. 'Preliminaries to Philostratus' On Heroes.' In Maclean \& Aitken 2001:xv-lxxxv.

Dué, C. \& Nagy, G. 2004. 'Illuminating the Classics with the Heroes of Philostratus.' In Maclean \& Aitken 2004:49-73.

Dzielska, M. 1986. Apollonius of Tyana in Legend and History. Rome: Bretschneider.

Eitrem, S. 1929. 'Zu Philostrats Heroikos.' Symbolae Osloenses 8:1-56.

Faraone, C.A. 2008. 'Household religion in Ancient Greece.' In J. Bodel \& S.M. Olyan (edd.), Household and Family Religion in Antiquity., 210-228. Malden, Mass.: Blackwell.

Festugière, A.-J. 1954. Personal Religion among the Greeks. Berkeley: University of California Press.

Follet, S. 2004. 'Philostratus's Heroikos and the regions of the Northern Aegean.' In Maclean \& Aitken 2004:221-235.

Gordon, R. 1990. 'Religion in the Roman Empire: the civic compromise and its limits.' In M. Beard and J. North (edd.) Pagan Priests: Religion and Power in the Ancient World., 235-255. London: Duckworth.

Hedreen, G. 1991. 'The cult of Achilles in the Euxine.' Hesperia 60:313-30.

Hilton, J.L. 2012. 'The cult of Neoptolemos at Delphi in Heliodoros' Aithiopika.' AClass 55:57-68.

Jones, C.P. 2001. 'Philostratus' Heroikos and its setting in reality.' JHS 121:141149.

Jones, C.P. 2010. New Heroes in Antiquity. From Achilles to Antinoos. Cambridge, Mass.: Harvard University Press.

Kerenyi, K. 1967. Eleusis: Archetypal Image of Mother and Daughter. Princeton: Princeton University Press.

Lane Fox, R. 1987. Pagans and Christians in the Mediterranean World from the Second Century A.D. to the Conversion of Constantine. New York: Knopf.

Liebeschuetz, J.H.W.G. 1979. Change and Continuity in Roman Religion. Oxford: Clarendon.

Maclean, J.K.B. 2004. 'Jesus as cult hero in the fourth gospel.' In Maclean \& Aitken 2004:195-218.

Maclean, J.K.B. \& Aitken, E.B. 2001. Flavius Philostratus: Heroikos. Atlanta: Society of Biblical Literature. 
Maclean, J.K.B. \& Aitken, E.B. 2002. Flavius Philostratus: On Heroes. Atlanta: Society of Biblical Literature.

Maclean, J.K.B. \& Aitken, E.B. (edd.) 2004. Philostratus's Heroikos. Religion and Cultural Identity in the Third Century C.E. Atlanta: Society of Biblical Literature.

Mantero, T. 1966. Ricerche sull' Heroikos di Filostrato. Genoa: University of Genoa.

Mestre, F. 2004. 'Refuting Homer in the Heroikos of Philostratus.' In Maclean \& Aitken 2004:127-141.

Morgan, J.R. 1982. 'History, romance and realism in the Aithiopika of Heliodoros.' ClAnt 1:221-265.

Nagy, G. 2001 'The sign of the hero: a prologue.' In Maclean \& Aitken 2001:xvxxxv.

Pache, C.O. 2004. 'Singing heroes: the poetics of hero cult in the Heroikos.' In Maclean \& Aitken 2004:3-24.

Rahim Shayegan, M. 2004. 'Philostratus's Heroikos and the ideation of the Late Severan policy toward Arsacid and Sasanian Iran.' In Maclean \& Aitken 2004:285-315.

Richter, G.M.A. 1929. 'A statue of Protesilaos in the Metropolitan Museum.' Metropolitan Museum Studies 1:187-200.

Rüpke, J. 2012. 'Lived ancient religion: questioning "cults" and "polis religion". Presentation of a new research program.' URL:

http://www.uni-erfurt.de/fileadmin/public-docs/Max-Weber-Kolleg/6pdfs/projekte/2012-Ruepke_Lived_anc_rel.pdf

Accessed 21 October 2013.

Rusten, J. 2004. 'Living in the past: allusive narratives and elusive authorities in the world of the Heroikos.' In Maclean \& Aitken 2004:143-158.

Schmid, W. 1887-1896. Der Atticismus in seinen Hauptvertretern. Hildesheim: G. Olms.

Solmsen, F. 1940. 'Some works of Philostratus the Elder.' TAPhA 71:556-572.

Solmsen, F. 1941. 'Philostratus'. RE 20.1:col. 156. Stuttgart: J.B. Metzlerscher.

Sourvinou-Inwood, C. 1990. 'What is polis religion?' In O. Murray \& S.R.F. Price (edd.) The Greek City from Homer to Alexander., 295-322. Oxford: Clarendon.

Swain, S. 1991. 'The reliability of Philostratus's "Lives of the Sophists".' ClAnt 10:148-163.

Swain, S. 1996. Hellenism and Empire. Language, Classicism, and Power in the Greek World AD 50-250. Oxford: Clarendon.

Wilamowitz-Moellendorff, U. 1959. Der Glaube der Hellenen, Vol. 2. 3rd edition. Darmstadt: Wissenschaftliche Buchgesellschaft.

Whitely, J. 1988. 'Early states and hero cults: a re-appraisal.' JHS 108:173-182. 
Whitmarsh, T. 2004. 'The harvest of wisdom: landscape, description, and identity in the Heroikos.' In Maclean \& Aitken 2004:237-249.

Woolf, G. 1997. 'Polis-religion and its alternatives in the Roman provinces.' In H. Cancik \& J. Rüpke (edd.), Römische Reichsreligion und Provinzialreligion., 71-84. Tübingen: Mohr Siebeck.

kirbyhirst@gmail.com 